\title{
PENGARUH KOMPETENSI DAN PENGEMBANGAN KARIR TERHADAP KINERJA PEGAWAI STUDI PADA BADAN KEPEGAWAIAN DAERAH (BKD) PROVINSI BANTEN
}

\author{
Asep Duddy Budiharta ${ }^{1}$, Nursusanto ${ }^{1}$, Komarudin ${ }^{1}$ \\ ${ }^{1}$ Pascasarjana UNIS-Tangerang \\ Email: nst1945@gmail.com
}

\begin{abstract}
Abstrak
Tujuan dalam penelitian ini adalah mengkaji kaitan antara Kompetensi, Kinerja, serta pengembangan karir pegawai Badan Kepegawaian Daerah (BKD) Provinsi Banten. Metode penelitian dalam penelitian ini adalah metode survey,dengan menggunakan pendekatan metode kuantitatif. Metode kuantitatif, ditinjau dari tingkat ekplanasi penelitian ini merupakan penelitian asosiatif dengan bentuk hubungan kausal. Populasi penelitian ini adalah Seluruh Pegawai Badan Kepegawaian Daerah (BKD) Provinsi Banten yang terdiri dari kepala BKD, Wakil Kepala BKD, Kepala Subbag, dan stafstafnya baik PNS maupun honorer yang berjumlah 94 orang. Teknik pengambilan sampel yang digunakan dalam penelitian ini ditentukan dengan menggunakan teknik purposive sampling, yaitu teknik penentuan sampel dengan pertimbangan tertentu. Kriteria dalam menentukan sampel adalah : "Seluruh Pegawai Badan Kepegawaian Daerah (BKD) Provinsi Banten yang berstatus Pegawai Pegawai Negeri Sipil (PNS)". yang berjumlah 65 orang pegawai, sehingga sampel dalam penelitian adalah sebanyak 65 orang pegawai. Hasil penelitian menunjukan bahwa : 1) Kompetensi memiliki pengaruh terhadap kinerja pegawai pada BKD Provinsi Banten. 2) Pengembangan karir pegawai berpengaruh terhadap kinerja pegawai pada BKD Provinsi Banten, 3) Terdapat pengaruh kompetensi dan pengembangan karir pegawai secara simultan terhadap kinerja pegawai pada BKD Provinsi Banten.
\end{abstract}

Kata kunci: Kompetensi, Pengembangan Karir, Kinerja Pegawai

\section{A. Pendahuluan}

Didalam sebuah organisasi baik itu instansi pemerintah maupun perusahaan swasta, peran aktif pegawai sangat penting sekali karena sebagai penentu keberhasilan sebuah organisasi dalam mencapai hasil sesuai dengan tujuan yang telah ditetapkan oleh organisasi tersebut. Salah satu indikator dalam mencapai tujuan yang telah ditetapkan tersebut adalah adanya kinerja dari pegawai atau karyawan sebagai salah satu kompenen sistem organisasi. Pegawai mempunyai peran yang utama dalam setiap kegiatan organisasi, karena pegawai menjadi perencana, pelaku, dan penentu terwujudnya tujuan sistem organisasi. Hal yang penting untuk meningkatkan kinerja organisasi atau instansi adalah bagaimana instansi itu mengelola kinerja para pegawai. Pengelolaan kinerja pegawai yang baik akan berdampak pada peningkatan kinerja instansi secara menyeluruh.

Untuk

mencapai pengembangan karir yang diharapkan, seorang pegawai hendaknya dapat menunjukkan kualitasnya, mengembangkan kompetensi dan kemampuan yang dimilikinya serta kinerja yang baik dalam pekerjaan yang dilakukannya. Hal tersebut demikian adanya dikarenakan sukses dalam karir seseorang merupakan tanggung jawab dirinya sendiri. Sehingga ia harus mengambil langkah-langkah tertentu untuk dapat mewujudkan karir yang diidamkan.

Pengembangan karir melalui peningkatan-peningkatan yang dilakukan secara individual untuk 
mencapai suatu rencana karir. Perubahan-perubahan pribadi yang dilakukan oleh seseorang untuk mencapai rencana karir, pengembangan karir juga dapat diartikan sebagai upaya pimpinan dalam mendayagunakan segenap potensi bawahannya dan mengupayakan adanya peningkatan produktivitas kerja.

Kinerja pada dasarnya adalah apa yang dilakukan atau tidak dilakukan oleh pegawai." Namun beberapa ahli mengartikan bahwa kinerja adalah hasil yang ditunjukkan oleh pegawai dalam menjalankan tugasnya. Kinerja adalah hasil kerja secara kualitas dan kuantitas yang dicapai oleh seorang pegawai dalam melaksanakan tugasnya sesuai dengan tanggung jawab yang diberikan kepadanya.(Mangkunegara,2009:18)"

Untuk menyelesaikan tugas atau pekerjaannya, seorang pegawai harus memiliki kesediaan, kemampuan dan juga pengetahuan. Karena kinerja merupakan suatu fungsi dari motivasi dan kemampuan. Kinerja merupakan suatu fungsi dari motivasi dan kemampuan. Untuk menyelesaikan tugas dan pekerjaan, seseorang harus memiliki derajat kesediaan dan tingkat kemampuan tertentu. Kesediaan dan keterampilan tidaklah cukup efektif untuk mengerjakan sesuatu tanpa pemahaman yang jelas tentang apa yang akan dikerjakan dan bagaimana mengerjakannya. Mengacu pada beberapa pendapat tersebut, diketahui bahwa kinerja merupakan hasil dari kemampuan kerja seorang pegawai dalam melaksanakan pekerjaannya sesuai dengan tugas dan tanggung jawab yang diembannya. Oleh sebab itu, kinerja seorang pegawai dikatakan baik apabila ia memiliki motivasi kerja yang tinggi, dapat menyelesaikan tugas yang diberikan olehnya tepat waktu, selalu memberikan kontribusi dan memiliki sikap serta perilaku yang baik sesuai standar kerja yang telah ditentukan baik oleh organisasi maupun nilainilai yang berlaku dalam lingkungan sekitar ia bekerja.

BKD mempunyai tugas pokok untuk melaksanakan penyusunan dan pelaksanaan kebijakan daerah di bidang kepegawaian. Selain itu, BKD mempunyai fungsi untuk merumuskan kebijakan teknis di bidang kepegawaian, memberi dukungan atas penyelenggaraan Pemerintahan Daerah di bidang kepegawaian, melakukan pembinaan dan pelaksanaan tugas di bidang kepegawaian, serta melaksanakan tugas lain yang diberikan oleh Gubernur sesuai dengan tugas pokok dan fungsinya. Untuk itu sumber daya aparatur perlu ditingkatkan agar lebih profesional. Sehingga masih perlu adanya peningkatan kualitas sumber daya aparatur yang menjadikan aparatur yang profesional dan kompeten. Maka dari itu Pemerintah dituntut untuk memiliki Sumber Daya Manusia (SDM) aparatur yang berkompeten, profesional, dan berintegritas sehingga kinerja pegawai menjadi baik dan dapat memberikan pelayanan prima kepada masyarakat dengan tujuan untuk meningkatkan efektivitas dan efisiensi dalam penyelenggaraan Pemerintahan. Selain itu posisi kerja yang tidak sesuai dengan kemampuannya (The right man in the right place), yang menyebabkan kinerja kurang maksimal sehingga mereka tidak bisa mengembangkan kemampuannya dam berimbas pada karir pegawai yang tidak berkembang.

\section{Landasan Teori}




\section{Penelitian Terdahulu}

Dalam penelitian ini penulis memaparkan tiga penelitian terdahulu yang relevan dengan permasalahan yang akan diteliti tentang pengaruh kompetensi dan pengembangan karir pegawai terhadap kinerja pegawai Badan Kepegawaian Daerah (BKD) Provinsi Banten.

a. Penelitian yang dilakukan oleh Lailin Niam (2016), menunjukkan bahwa ada pengaruh secara positif dan signifikan kompetensi dan pengembangan karir terhadap kinerja pegawai dengan komitmen organisasi sebagai variabel intervening. Kompetensi mempunyai pengaruh terhadap kinerja pegawai melalui komitmen organisasi sebagai variabel intervening.

b. Luvita Tiara Dewi (2015) menunjukkan bahwa kompensasi berpengaruh terhadap kinerja karyawan KBM IK Brumbung Perum Perhutani Jawa Tengah. Kompensasi diukur dengan kompensasi yang diterima karyawan dalam bentuk nonfinansial seperti memberikan penghargaan, kompensasi yang diterima karyawan dalam bentuk finansial seperti memberikan gaji, upah, bonus dan tunjangan.

c. Lumbantoruan (2008) menunjukkan bahwa pengembangan karyawan $(\mathrm{X}=$ 4,29 dan $\mathrm{Sc}=132)$ dan kinerja karyawan $\quad(Y=4,67 \quad$ dan $\mathrm{Sc}=135,1)$. Jadi dapat disimpulkan bahwa pengembangan karir karyawan mempunyai hubungan yang positif dan signifikan terhadap peningkatan kinerja karyawan.

2. Kompetensi

\section{a. Definisi Kompetensi}

Kompetensi merupakan karakter dasar orang yang mengindikasikan cara berperilaku atau berpikir, yang berlaku dalam cakupan situasi yang sangat luas dan bertahan untuk waktu yang lama.

Kompetensi merujuk kepada karakteristik yang mendasari perilaku yang menggambarkan motif, karateristik pribadi (ciri khas), konsep diri, nilai-nilai, pengetahuan atau keahlian yang dibawa seseorang yang berkinerja unggul di tempat kerja.

Menurut Keputusan Kepala Badan Kepegawaian Negara No 46A Tahun 2003 yang menyatakan bahwa kompetensi adalah kemampuan dan karakteristik yang dimiliki oleh seorang pegawai negeri sipil berupa pengetahuan, keterampilan, dan sikap perilaku yang diperlukan dalam pelaksanaan tugas jabatannya, sehingga pegawai negeri tersebut dapat melaksanakan tugasnya secara profesional, efektif dan efisien.

Menurut Hutapea dan

Thoha (2008) menjelaskan bahwa kompetensi adalah sebagai berikut : "Kemampuan dan kemauan dalam melakukan sebuah tugas dengan kinerja yang efektif dan efisien untuk mencapai tujuan organisasi."

Menurut Spencer \& Spencer dalam Moeheriono (2010) menjelaskan bahwa 
kompetensi adalah sebagai berikut :

$\begin{array}{lr}\text { "Karakteristik } & \text { yang } \\ \text { mendasari } & \text { seseorang } \\ \text { berkaitan } & \text { dengan } \\ \text { efektivitas } & \text { kinerja } \\ \text { individu } & \text { dalam } \\ \text { pekerjaannya } & \text { atau } \\ \text { karakteristik } & \text { dasar }\end{array}$
individu yang dimiliki hubungan kausal atau sebagai sebab akibat dengan kriteria yang dijadikan acuan, efektif atau berkinerja prima atau superior ditempat kerja atau pada situasi tertentu."

Kompetensi terletak pada bagian dalam setiap manusia dan selamanya ada pada kepribadian seseorang dan dapat memprediksikan tingkah laku dan performansi secara luas pada semua situasi dan tugas pekerjaan (job tasks) (Spencer \& Spencer dalam Moeheriono, 2010).

Wibowo

menyatakan kompetensi adalah suatu kemampuan untuk melaksanakan atau melakukan suatu pekerjaan yang dilandasi atas keterampilan dan pengetahuan serta didukung oleh sikap kerja yang dituntut oleh pekerjaan tersebut.

$$
\text { Yudistira }
$$

dan

Siwantara (2012) menyebutkan bahwa kompetensi berpengaruh positif dan signifikan secara langsung terhadap kinerja pegawai. Hal ini didukung oleh penelitian dari Sulistyaningsih (2009) bahwa kompetensi berpengaruh signifikan positif terhadap kinerja karyawan.

b. Jenis Kompetensi
Sebagai lanjutan dari definisi kompetensi yang telah dibuat, menindaklanjuti dengan pembuatan klasifikasi kompetensi:

1) Kompetensi Inti :

2) Kompetensi Fungsional

3) Kompetensi Perilaku

4) Kompetensi Peran

\section{Pengembangan Karir}

a. Pengertian Pengembangan Karir

Karir adalah rangkaian sikap dan perilaku yang berkaitan dengan pengalaman dan aktivitas kerja selama rentang waktu kehidupan seseorang dan rangkaian aktivitas kerja yang terus berkelanjutan.

Menurut Irianto (2001:94), pengertian karir meliputi elemen-elemen obyektif dan subyektif. Elemen obyektif berkenaan dengan kebijakan-kebijakan pekerjaan atau posisi jabatan yang ditentukan organisasi, sedangkan elemen subyektif menunjuk pada kemampuan seseorang dalam mengelola karir dengan mengubah lingkungan obyektif (misalnya dengan mengubah pekerjaan/jabatan) atau memodifikasi persepsi subyektif tentang suatu situasi (misalnya dengan mengubah harapan).

Dengan demikian dapat disimpulkan bahwa karir merupakan suatu rangkaian perubahan nilai, sikap, dan perilaku serta motivasi yang terjadi pada setiap individu selama rentang waktu kehidupannya untuk menemukan secara jelas 
keahlian, tujuan karir, dan kebutuhan untuk pengembangan, merencanakan tujuan karir, dan secara kontinu mengevaluasi, merevisi, dan meningkatkan rancangannya. Karir juga merupakan suatu proses kemitraan interaksi dalam tahapan dan kerja sama antara organisasi/perusahaan atau manajemen, atasan langsung, dan individu itu sendiri.

Ada sejumlah prinsip yang perlu diperhatikan dalam kaitannya dengan pengembangan karir. Pertama, pekerjaan itu sendiri memiliki pengaruh paling besar terhadap pengembangan karir. Kedua, jenis keterampilan baru yang akan dibutuhkan ditentukan oleh persyaratan jabatan yang spesifik. Ketiga, pengembangan karir akan terjadi hanya apabila seseorang belum memperoleh keterampilan yang disyaratkan oleh suatu jabatan tertentu.

1) Membuktikan tanggung jawab sosial

Pengembangan

karir adalah suatu cara menciptakan iklim kerja yang positif dan pegawaipegawai memiliki mental lebih sehat.

2) Membantu memperkuat pelaksanaan programprogram pemerintah agar tujuan organisasi tercapai.

3) Mengurangi keusangan profesi dan manajerial Pengembangan karir dapat menghindarkan diri dari keusangan dan kebosanan profesi dan manajerial.

4) Menggiatkan analisis dari keseluruhan pegawai Pengembangan

karir dimaksudkan untuk mengintegrasikan

perencanaan kerja dan kepegawaian.

5) Menggiatkan suatu pemikiran (pandangan) untuk jangka waktu panjang

Pengembangan karir berhubungan dengan jangka waktu yang panjang. Hal ini karena penempatan suatu posisi jabatan memerlukan persyaratan dan kualifikasi yang sesuai dengan porsinya.

\section{Kinerja Pegawai}

\section{a. Pengertian Kinerja}

Menurut Armstrong dan Baron (dalam Wibowo, 2007:8) kinerja merupakan hasil pekerjaan yang mempunyai hubungan yang kuat dengan tujuan strategis organisasi, kepuasan konsumen, dan memberikan kontribusi pada ekonomi. Dengan demikian, kinerja adalah tentang melakukan pekerjaan dan hasil yang dicapai dari pekerjaan tersebut. Kinerja adalah tentang apa yang dikerjakan dan bagaimana cara mengerjakannya. Menurut Mangkunegara (2007:67) kinerja merupakan hasil kerja secara kualitas dan kuantitas yang dicapai oleh seorang pegawai dalam melaksanakan tugasnya sesuai dengan tanggung jawab yang diberikan kepadanya. 
Berdasarkan beberapa pengertian di atas maka dapat ditarik kesimpulan bahwa kinerja merupakan hasil kerja yang dicapai seorang pegawai dalam melaksanakan pekerjaan yang sesuai dengan tanggung jawab yang diberikan kepada pegawai tersebut.

b. Faktor-Faktor

yang

Mempengaruhi

Kinerja

Pegawai

Hasibuan

(2006)

mengungkapkan bahwa

kinerja merupakan gabungan tiga faktor penting, yaitu kemampuan dan minat seorang pekerja, penerimaan atas penjelasan delegasi tugas, dan peran serta tingkat motivasi pekerja. Apabila kinerja setiap individu atau pegawai baik, maka diharapkan kinerja organisasi akan baik pula.

Menurut Nitisemito (2001), terdapat berbagai faktor yang mempengaruhi kinerja pegawai, antara lain:

1) Kompetensi

2) Jumlah dan komposisi dari kompensasi yang diberikan

3) Penempatan kerja yang tepat

4) Pelatihan dan promosi

5) Rasa aman di masa depan (dengan adanya pesangon dan sebagainya)

6) Hubungan dengan rekan kerja

7) Hubungan dengan pemimpin

Menurut Mathis dan Jackson (2002), faktor-faktor yang mempengaruhi kinerja individu tenaga kerja, yaitu:
1) Pengetahuan, keterampilan, dan sikap pegawai

2) Motivasi yang diterima dapat melalui sistem penghargaan seperti kompensasi dan pengembangan karir yang diperoleh pegawai.

3) Lingkungan kerja

4) Penempatan kerja yang diterima pegawai

5) Hubungan mereka dengan organisasi

Menurut Gibson (dalam Mangkunegara, 2005), ada 3 faktor yang berpengaruh terhadap kinerja:

1) Faktor individu : kemampuan, keterampilan, latar belakang keluarga, pengalaman kerja, tingkat sosial, dan demografi seseorang.

2) Faktor psikologis : persepsi, peran, sikap, kepribadian, motivasi dan kepuasan kerja.

3) Faktor organisasi: struktur organisasi, desain pekerjaan, penempatan kerja, kepemimpinan, pengembangan karir pegawai, dan sistem penghargaan (reward system).

Dari beberapa faktor diatas, maka dapat disimpulkan bahwa ada banyak faktor yang mempengaruhi kinerja pegawai. Dintaranya faktor internal antara lain: kompetensi, disiplin kerja, kepuasan kerja dan motivasi pegawai. Faktor eksternal meliputi: gaya kepemimpinan, lingkungan kerja, kompensasi dan sistem manajemen yang 
terdapat di intansi tersebut (penempatan kerja, pengembangan karir, komunikasi, komitmen organisasi, dll). Faktor-faktor tersebut hendaknya perlu diperhatikan oleh pimpinan sehingga kinerja pegawai dapat optimal.

\section{Kerangka Berpikir}

Kompetensi

merupakan

karakter dasar orang yang mengindikasikan cara berperilaku atau berpikir, yang berlaku dalam cakupan situasi yang sangat luas dan bertahan untuk waktu yang lama. Kompetensi merujuk kepada karakteristik yang mendasari perilaku yang menggambarkan motif, karateristik pribadi (ciri khas), konsep diri, nilai-nilai, pengetahuan atau keahlian yang dibawa seseorang yang berkinerja unggul di tempat kerja.

Pengembangan karir pegawai dapat dilakukan melalui pelatihan dan pendidikan, promosi, dan mutasi. Menurut Panggabean (2004:17), pada hakikatnya pengembangan karir pegawai bertujuan untuk menyesuaikan persyaratan atau kualifikasi yang dibutuhkan untuk melaksanakan pekerjaannya (sekarang atau pada masa mendatang) dengan kualifikasi yang dimiliki pegawai. Dengan adanya pengembangan karir yang diselenggarakan oleh perusahaan, maka karyawan akan termotivasi secara pribadi dalam meningkatkan kinerjanya yang pada akhirnya akan berdampak positif pada tercapainya tujuan organisasi.

Mangkunegara

menyatakan bahwa kinerja pegawai adalah hasil kerja secara kualitas dan kuantitas yang dicapai oleh seseorang pegawai dalam melaksanakan tugasnya sesuai dengan tanggung jawab yang diberikan kepada pegawai tersebut.

\section{B. Metode Penelitian}

Desain penelitian ini menggunakan pendekatan metode kuantitatif survey. Survey dalam untuk mendapatkan data yang memberikan gambaran tentang hubungan yang bersifat sebab akibat antara kompetensi (X1) dan pengembangan karir (X2) dan kinerja pegawai (Y). Pengumpulan data misalnya dengan mengedarkan koisioner, tes, wawancara dan sebagainya untuk mengetahui pengaruh atau sebab akibat variabel bebas terhadap variabel terikat.

Populasi penelitian ini adalah Seluruh Pegawai Badan Kepegawaian Daerah (BKD) Provinsi Banten yang terdiri dari kepala BKD, wakil Kepala BKD, kepala subag, dan stafstafnya baik PNS maupun honorer yang berjumlah 94 orang pegawai.

Teknik pengambilan sampel yang digunakan dalam penelitian ini ditentukan dengan menggunakan teknik purposive sampling. Berdasarkan kriteria tersebut hanya 65 orang pegawai Badan Kepegawaian Daerah (BKD) Provinsi Banten yang bestatus PNS, sehingga sampel dalam penelitian adalah sebanyak 65 orang.

Sumber data yang diharapkan dapat memberikan informasi sesuai dengan yang diperlukan diperoleh dari:

1) Responden, yaitu orang-orang yang terkait langgsung dengan yakni Pegawai Badan Kepegawaian Daerah (BKD) Provinsi Banten dan dapat menerangkan tentang dirinya sendiri sehubungan dengan kegiatan yang akan diteliti. 
2) Literatur, yaitu catatan/dokumen yang berhubungan dengan pembahasan masalah dala penelitian

Cara yang ditempuh dalam pengumpulan data adalah:

1) Observasi, yaitu melakukan pengamatan langsung terhadap objek yang diteliti.

3) Studi Pustaka, yaitu teknik pengumpulan data dengan cara membaca literatur-literatur yang berhubungan dengan masalah yang akan diteliti.

4) Angket, yaitu teknik pengumpulan data dengan cara membagikan form isian kepada responden

Setelah data-data yang penulis peroleh melalui pengumpulan data sebagaimana diterangkan di atas, maka tahap selanjutnya adalah menganalisa data yang selanjutnya diproses atau dikerjakan sehingga dapat menampilkan kebenaran yang dipakai untuk menjawab persoalan yang telah diajukan dalam penelitian.

\section{Uji Asumsi Klasik}

a. Pengujian Normalitas

Uji normalitas perlu dilakukan untuk menentukan alat statistik yang diperlukan. Jika data yang diperoleh terdistribusi normal dan atau variasinya tidak sama, maka pengujian hipotesis dilakukan dengan alat statistik nonparametrik. Tujuan uji normalitas menurut Ghozali (2013) adalah ingin mengetahui apakah dalam model regresi variabel pengganggu atau residual memiliki distribusi normal. Ada dua cara untuk mendeteksi apakah residual berdistribusi normal atau tidak yaitu dengan analisis grafik (grafik normal probability plot) dan uji satatistik (uji kolmogorov-smirnov).

b. Uji Multikolonieritas

Menurut

Ghozali, (2013) uji multikolonieritas bertujuan menguji apakah model regresi ditemukan adanya korelasi antar variabel bebas (independen). Model regresi yang baik seharusnya tidak terjadi korelasi antar variabel independen. Jika antar variabel independen ada korelasi kurang dari 95\%, dan nilai tolerance $>0.1$ juga nilai VIF < 10 maka dikatakan tidak terjadi adanya multikolonieritas. (Ghozali, 2013).

Menurut Ghozali (2013), cara yang dapat dilakukan jika terjadi multikolinearitas yaitu:

1) Mengeluarkan satu atau lebih variabel independen yang mempunyai korelasi tinggi dari model regresi dan identifikasi variabel independen lainnya untuk membantu prediksi,

2) Menggabungkan data cross section dan time series,

3) menambah data penelitian.

\section{Uji Hipotesis}

Hipotesis dalam penelitian ini diuji dengan menggunakan model regresi berganda. Model regresi berganda bertujuan untuk memprediksi besar variabel dependen dengan menggunakan data variabel independen yang sudah diketahui besarnya (Santoso, 2000:163).

Dalam

uji

\section{a. Uji Korelasi Parsial}


Analisis korelasi parsial (Partial Correlation) digunakan untuk mengetahui hubungan antara dua variabel dimana variabel lainnya yang dianggap berpengaruh dikendalikan atau dibuat tetap (sebagai variabel kontrol).

\section{b. Koefisien Determinasi (KD)}

(KD) bertujuan untuk mengetahui seberapa besar kemampuan variabel independen menjelaskan variabel dependen.

c. Uji t

Uji ini menunjukkan seberapa jauh pengaruh satu variabel penjelas atau independen secara individual dalam menerangkan variasi variabel dependen dan digunakan untuk mengetahui ada atau tidaknya pengaruh masing-masing variabel independen yang diuji pada tingkat signifikansi 0,05 (Ghozali, 2013).

\section{Hasil Penelitian dan Pembahasan}

Penelitian dilakukan kepada 65 responden yang merupakan pegawai Badan Kepegawaian Daerah (BKD) Provinsi Banten dengan penyebaran aket mengenai kompetensi, Pengembangan Karir dan Kinerja Pegawai.

Hasil penelitian diketahui bahwa sebagian besar responden berusai antara 31 - 40 tahun yaitu sebanyak 39 orang atau $60 \%$, hal ini dapat disimpulkan bahwa usia pegawai BKD Provinsi Banten di antara 31 - 40 tahun ini merupakan usia yang sangat produktif, stabil dan enerjik dengan jenis kelamin laki-laki sebanyak 35 orang dan perempuan sebanyak 30 orang, hal ini bererti bahwa untuk menjadi pegawai pada BKD Provinsi Banten tidak dipengaruhi oleh perbedaan gender akantetapi lebih kepada kualitas pegawai individu itu sendiri. Ratarata tingkat pendidikan responden adalah Sarjana (S1) yaitu sebesar 37 orang atau 57\%, hal ini dapat disimpulkan bahwa pegawai BKD Provinsi Banten dituntut memiliki wawasan dan pengetahuan yang baik.

Pegawai BKD Provinsi Banten memiliki kompetensi yang baik sesuai bidang pekerjaan dan jabatan yang diemban. Hal ini sesuai jawaban responden untuk skor aktual sebesar 2478 atau rata-rata 76,2\% yang tergolong pada katagori baik, sedangkan pengembangan karir pegawai BKD Provinsi Banten memiliki pengembangan karir yang baik sesuai hasil jawaban responden untuk skor aktual sebesar 2466 atau rata-rata $75,9 \%$. Sedangkan untuk kinerja pegawai, dapat dilihat bahwa kinerja pegawai BKD Provinsi Banten baik hal dapat dilihat bahwa jawaban responden untuk skor aktual sebesar 2463 atau rata-rata 75,5\% hal ini tergolong pada katagori baik.

Berdasarkan hasil hasil pengujian hipotesis kompetensi pengaruhnya terhadap kinerja pegawa dapat dilihat dari nilai $t$ hitung sebesar 5,758 dan $\mathrm{t}$ table dengan sigifikasin $5 \%(\mathrm{df}=\mathrm{n}-\mathrm{k}, \mathrm{df}=65-3=$ 62) maka $t$ table $=1.669$, hal ini berarti t hitung $>\mathrm{t}$ table yaitu 5,758 $>1,669$. Sehingga dapat disimpulkan bahwa terdapat pengaruh kompetensi terhadap kinerja pegawai pada BKD Provinsi Banten. Hal ini sesuai dengan hasil penelitian yang dilaukan oleh Lailin Niam (2016), dimana hasil penelitiannya terdapat pengaruh secara positif dan signifikan 
kompetensi dan pengembangan karir terhadap kinerja pegawai

Sedangkang hasil pengujian hipotesis pengembangan karir menunjukkan nilai $\mathrm{t}$ hitung sebesar 4,697 dan t table dengan sigifikasin $5 \%(\mathrm{df}=\mathrm{n}-\mathrm{k}, \mathrm{df}=65-3=62)$ maka $\mathrm{t}$ table $=1.669$, hal ini berarti t hitung > t table, yaitu 4,697 > 1,669. Sehingga dapat disimpulkan bahwa terdapat pengaruh pengembangan karir terhadap kinerja pegawai pada BKD provinsi Banten. Hal ini sesuai dengan penelitian yang pernah dilakukan oleh Lailin Niam (2016), Lumbantoruan (2008) dan juga Luvita Tiara Dewi (2015) yang menyatakan bahwa pengembangan karir berpengaruh terhadap kinerja pegawai,

Untuk menguji pengaruh kompetensi dan pengembangan karir secara simultan terhadap kinerja pegawai menggunakan uji F. Hasil perhitungan regresi secara simultan diperoleh hasil perhitungan statistik menunjukkan nilai $\mathrm{F}$ hitung $=$
19,908, sedangkan nlai $F$ table dengan $\mathrm{df}=\mathrm{k}-1=3-1=2$, dan $\mathrm{df} 2=\mathrm{n}-\mathrm{k}$ $=65-3=62$ adalah didapat $\mathrm{F}$ table sebesar 3,15. Hal ini berarti F hitung $>$ F table, yaitu 19,908 > 3,15. Maka dapat disimpulkan bahwa terdapat pengaruh yang signifikan kompetensi dan pengembangan karir secara simultan terhadap kinerja pegawai pada BKD Provinsi Banten.

\section{Kesimpulan}

Berdasarkan hasil penelitian dan pembahasan yang telah dijelaskan sebelumnya, dapat ditarik kesimpulan sebagai berikut:

1. Terdapat pengaruh kompetensi terhadap kinerja pegawai pada BKD Provinsi Banten.

2. Terdapat pengaruh pengembangan karir pegawai terhadap kinerja pegawai pada BKD Provinsi Banten

3. Terdapat pengaruh kompetensi dan pengembangan karir pegawai secara simultan terhadap kinerja pegawai pada BKD Provinsi Banten.

\section{Daftar Pustaka}

Alex S. Nitisemito, 2001. Manajemen Personalia, Jakarta : Graha Indonesia

Arikunto, Suharsimi, 2012, Prosedur Penelitian, Suatu Praktek, Bina, Jakarta

Achmad S.Ruky. 2006. Sistem Manajemen Kinerja. Jakarta : PT Bumi Aksara

Azhar, Arsyad, 2009. Media Pembelajaran, Jakarta : Raja Grafindo Persada

Basri, A. F. M., dan Rivai, V.2005. Performance appraisal. Jakarta: PT. Raja. Grafindo Persada

Djamaludin Tandjung; Inu Kencana Syafiie; Supardan Modeong, 1999. Ilmu Administrasi Punlik, Jakarta :Rineka Cipta

Ghozali, Imam. 2013. Aplikasi Analisis Multivariate Dengan Program SPSS. Semarang : BP Universitas Diponegoro

Handayaningrat, Soewarno. 1992. Pengantar Studi Ilmu Administrasi dan. Manajemen. Jakarta : Cv Haji Masagung

Hutapea, Parulian dan Nuriannan Thoha, 2008 Kompetensi Plus. Jakarta : PT. Gramedia Pustaka Utama

Handoko, T. Hani, 2006, Manajemen Personalia dan Sumber Daya Manusia, B.P.F.E. UGM, Yogyakarta 
Irtanto, 2001. Dinamika Politik Lokal Era Otonomi Daerah, Pustaka Pelajar, Yogyakarta.

Miftah Thoha, 1983. Perilaku Organisasi, Jakarta : Rajawali

Moeheriono. 2010. Pengukuran Kinerja Berbasis Kompetensi. Surabaya: Ghalia

Malayu Hasibuan, S.P. 2006, Manajemen Sumber Daya Manusia. Bumi Aksara. Jakarta.

Mathis, Jackson. 2002. Manajemen Sumber Daya Manusia. Salemba Empat,. Jakarta

Mangkunegara A.A Anwar Prabu. 2005. Manajemen Sumber Daya Manusia Perusahaan. Bandung : Remaja Rosda Karya

Palan. 2007. Competency management: Teknis Mengimplementasikan Manajemen Sumber Daya Manusia Berbasis Kompetensi Untuk Meningkatkan Daya Saing Organisasi. PPM. Salemba Empat, Jakarta

Siagian, Sondang. 2007. Fungsi-fungsi manajerial edisi revisi. Jakarta. Bumi Aksara

Silalahi, Ulber. 2009. Metode Penelitian Sosial. Bandung; PT. Refika Aditama.

Simamora, Henry. 2006. Manajemen Sumber Daya Manusia, Edisi 2, STIE YKPN. Yogyakarta

Sugiono. 2009. Metodologi Penelitian. Bandung . Alfabeta

Tjiptoherijanto, P. 2015. Proyeksi Penduduk, Angkatan Kerja, Tenaga Kerja, dan Peran serikat Pekerja dalam Peningkatan Kesejahteraan. Majalah Perencanaan Pembangunan

Wibowo. 2007. Manajemen Kinerja. PT. Raja Grafindo Parsada: Jakarta

William H. Newman, 1961. The Process of Management (London: Prentice Hall, Inc. 